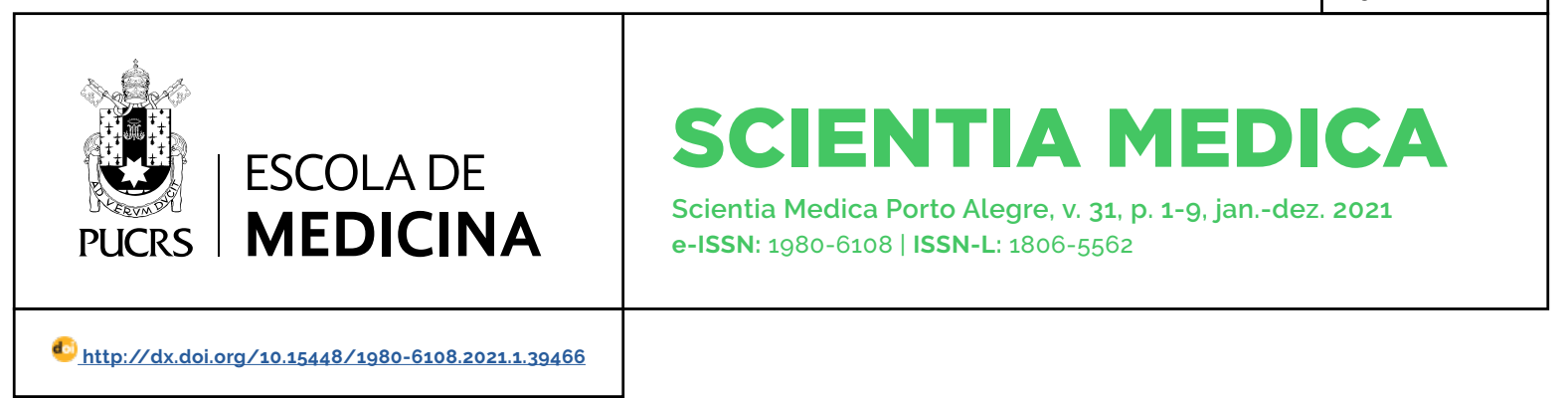

RESEARCH ARTICLE

\title{
Association between sleep disorders and child violence assessed in Southern Brazil
}

\author{
Associação entre distúrbios do sono e violência infantil avaliada no Sul do Brasil
}

\section{Lilian Bertoletti ${ }^{1}$}

orcid.org/0000-0002-9327-5446

lilianbertt93@gmail.com

\section{Fernanda Cristina \\ Scarpa ${ }^{1}$}

lattes.cnpq.br/5400595096590876

drascarpa@yahoo.com.br

\section{Michelli Osanai da}

Costa ${ }^{2}$

orcid.org/0000-0003-4853-0900

michi.osanai@gmail.com

Eduarda Correa Freitas ${ }^{3}$ orcid.org/0000-0002-0218-2296 ecfreitas@hcpa.edu.br

\section{Luana Goulart Marin ${ }^{1}$}

orcid.org/0000-0002-0325-6269 luana.gmarin@yahoo.com.br

\section{Rafael Miranda de \\ Marco $^{1}$}

orcid.org/0000-0001-9184-6826 rafael_m.demarco@hotmail.com

\section{Rosemary de Oliveira Petkowicz ${ }^{2}$}

orcid.org/0000-0003-3073-872X rosepetkowicz@gmail.com

Received on: Nov. $2^{\text {nd }}, 2020$. Approved on: Aug. 26 th 2021. Published on: Sep. $29^{\text {th }}, 2021$.

\section{(c) (i)}

Artigo está licenciado sob forma de uma licença Creative Commons Atribuição 4.0 Internacional.

\section{Abstract}

Aims: identifying sleep disorders (SDs) in children who experienced child maltreatment.

Methods: the study evaluated the sleep pattern of 123 children (from 2 to 10 years old), who received assistance with child maltreatment, based on the Children's Sleep Habits Questionnaire (CSHQ) - applied in a medical consultation after confirmation of the veracity of the child's report of a violation. The study applied the questionnaire to children seen by doctors in the sector for 11 months

Results: among the children evaluated, $66.7 \%$ had SDs. The sample profile was predominantly female (59.3\%) and aged between 4 and 7 years old (48.8\%). Physical violence was found in $40.7 \%$ of the children, in addition to sexual (35.8\%), psychological (24.4\%), negligence (14.6\%) and other types of violence (OTV) (4.5\%). SDs are significantly associated with sexual, psychological and OTV $(p=0.016)$. Regarding the subscales, there was a significant difference between the age groups in the bedtime resistance (BR) factor score $(p=0.033)$. The BR characteristic typifies sexual, psychological and OTV. Sleep anxiety (SA) typifies more psychological, sexual and OTV. Night awakenings (NAs) typify psychological, sexual and physical violence. According to the type of violence, significant differences were found in SA ( $p=0.039)$, NAs $(p=0.026)$ and BR $(p=0.004)$.

Conclusions: the outcomes highlight the association between SDs and child maltreatment. Certain types of violence have a greater negative impact on children's sleep and correlate with specific SD.

Keywords: sleep disorders, child abuse, child maltreatment, domestic violence, sexual abuse.

\section{Resumo}

Objetivos: identificar distúrbios do sono em crianças que sofreram maus-tratos infantis.

Métodos: o estudo avaliou o padrão de sono de 123 crianças (de 2 a 10 anos) atendidas por relatos de maus-tratos, com base no Questionário de Hábitos de Sono Infantil (CSHQ) - aplicado em uma consulta médica após confirmação da veracidade do relato de violação da criança. O estudo aplicou o questionário a crianças atendidas no setor durante o periodo de 11 meses.

Resultados: dentre as crianças avaliadas, $66.7 \%$ apresentavam distúrbios do sono. O perfil da amostra foi predominantemente feminino (59,3\%) e com idade entre quatro e sete anos ( $48,8 \%$ ). Violência física foi encontrada em $40,7 \%$ das crianças, além de sexual $(35,8 \%)$, psicológica $(24,4 \%)$, negligência $(14,6 \%)$ e outros tipos de violência (4.5\%). Os distúrbios do sono estão significativamente associados à violência sexual, psicológica e a outros tipos de violência (OTV) ( $p=0,016)$. Em relação às subescalas, houve diferença significativa entre as faixas etárias nos escores de resistência em ir para a cama $(p=0,033)$. A característica resistência em ir para a cama tipifica a violência sexual, psicológica e OTV. Ansiedade do

\footnotetext{
Universidade Luterana do Brasil (ULBRA), Porto Alegre, RS, Brasil.

Centro de Referência em Atendimento Infanto-juvenil (CRAI); Hospital Universitário de Canoas (HU), Canoas, RS, Brasil.

Universidade Federal do Rio Grande do Sul (UFRGS), Porto Alegre, RS, Brasil.
} 
sono tipifica mais a violência psicológica, sexual e OTV. O despertar noturno tipifica a violência psicológica, sexual e física. De acordo com o tipo de violência, foram encontradas diferenças significativas na ansiedade do sono $(p=0,039)$, despertar noturno $(p=0,026)$ e resistência em ir para a cama $(p=0,004)$.

Conclusões: os resultados evidenciam a associação entre distúrbios do sono e violência infantil. Certos tipos de violência têm um impacto negativo maior no sono infantil e se correlacionam a distúrbios do sono especificos.

Palavras-chave: distúrbios do sono, abuso infantil, maus-tratos infantis, violência doméstica, abuso sexual.

ABBREVIATIONS: BR, bedtime resistance; CSHQ, Children's Sleep Habits Questionnaire; NAs, night awakenings; OTV, other types of violence; SA, sleep anxiety; SDS, sleep disorders; SDB, sleep-disordered breathing; SOD, sleep outset delay.

\section{Introduction}

The World Health Organization defines violence as "the intentional use of force or physical power against another person that results (or is highly likely to result) in injury, death, psychological damage or inadequate development" (1). Violence is a complex phenomenon, associated with specific sociocultural and political contexts and dynamics (2).

In its report (1), the World Health Organization classifies violence against children into physical abuse, sexual abuse, psychological abuse and neglect. Among them, neglect is prevalent (50\%), followed by physical abuse (33.3\%), psychological abuse $(8.3 \%)$ and sexual abuse $(8.3 \%)(3.4)$. One example of the manifestation of the latter is a study that assessed the profile of children and adolescents who have suffered sexual abuse in Rio Grande do Sul which has shown that $39.35 \%$ of them were between 10 and 14 years old, followed by $30.64 \%$ who were between 5 and 9 , with a predominance of girls (5).

Furthermore, mistreatment at an early age has a greater negative impact: increased anxiety, depressive disorders, aggressiveness and withdrawn behavior, suicidal thinking and/or intention, eating disorders, sleep disorders (SDs) and behavioral problems such as bullying and rule-breaking habits (4, 6-9). It is important to highlight that the violence must also be identified according to emotional or nutritional deprivation as well as reports of developmental failures, weight changes and schooling problems (3).
More specifically, disruptive nocturnal behaviors are considered a class of SDs that includes nightmares, night terror and dream-enacting behaviors. According to the study carried out by Cecil et al., with an age range between 16 to 24 years old, disruptive nocturnal behaviors have been associated with females and older age (10). Also, emotional, and sexual abuse has been associated with disruptive nocturnal behaviors, with a greater association with the emotional effect $(8,10)$.

In addition, several studies have reported SDs in children who were exposed to trauma, especially in those who have experienced child violence ranging from $16 \%$ to $40 \%$ of occurrence. About $20 \%$ to $30 \%$ of children have experienced nightmares and $20 \%$ to $43 \%$ have difficulty sleeping (8).

There are several symptoms of SDs, the fear when going to sleep in the dark being the one that has appeared the most. It has been observed in $23.4 \%$ of the abused children, while $13.9 \%$ of the non-abused children have also presented such alteration. Symptoms of night terror make up 1.8\% versus $0.5 \%$; those of nightmares, $4.4 \%$ versus $1.7 \%$; those of early awakening, $3.7 \%$ versus $1.9 \%$; and those of daytime sleepiness, $9.9 \%$ versus 6.9\%. Moreover, SDs are highly prevalent among sexually abused individuals, particularly females in adulthood, and are manifested in an increase of awakenings, nighttime movement, sleep paralysis, nightmares, and insufficient sleep $(11,12)$.

Additionally, when dealing with sociodemographic information about the association between child sexual abuse and SDs in preschoolers, there have been negative associations between SDs, maternal age and their education level (12).

Furthermore, according to the study carried out by Baiden et al., about $11 \%$ of men and $17 \%$ of women who experienced childhood adversity have shown changes in their daily sleep patterns. It has also been evidenced that $14.2 \%$ of the interviewees had disturbed sleep. Among the most prevalent adversities, $40.3 \%$ of physical violence, $16 \%$ of domestic violence and $10 \%$ of situations of sexual violation have been found (13).

Lastly, it is worth highlighting that SDs in adulthood are related to excessive alcohol 
consumption, personality disorders, attention deficit and hyperactivity disorder (and several other reasons). They also show a correlation with obesity, chronic respiratory disease, stroke, heart disease, cancer and diabetes $(13,14)$. Child abuse has already been linked to smaller total brain size, leading to synaptic changes and reduced brain activity on electroencephalograms (15). Hence the importance of an early assessment of SDs among children.

Thus, the present study aimed to identify SDs and their characteristics in children who have been victims of child violence. Therefore, its goal is to assist in the prevention and the onset and aggravation of diseases (13).

\section{Methods}

The study protocol has been approved by the Ethics Committee of the Lutheran University of Brazil, under the number 3.291.302. Ethical principles are following resolution number 466/2012 of Brazil's National Health Council. The study has preserved the participants' anonymity as well as not taken any damage or risks to them.

This is a descriptive observational crosssectional study with a target population of children between 2 and 10 years old, victims of child violence or exposure to home violence who have received care by the Reference Center for Child and Adolescent Care in the University Hospital of Canoas. The period of medical care appointments comprised 11 months, with a retrospective collection from October 2018 to August 2019 . Children's Sleep Habits Questionnaire (CSHQ) was applied only at the child's first appointment.

The CSHQ is a retrospective tool answered by children's parents or legal guardians to assess sleep behavior in school-age children. The questions were selected to include the presence of symptoms of the most common childhood SDs, according to the International Classification of Sleep Disorders. The questionnaire was the chosen research instrument, with the addition of five questions: age (years), sex, use of medications and/or diagnosis of psychiatric disorders and types of violence suffered $(1,16)$. The collection of information through the questionnaire has been performed by a medical professional who was registered in an electronic medical record, having parents or companions as an informant source. The answers to the inferred questions have been based on the children's sleep habits during the week before or during a recent typical week.

Quantitative variables (age in years), qualitative variables (male or female) and categorical variables (types of violence suffered - physical violence, sexual violence, psychological violence, neglect and other forms of violence - which, in this study, only accounted cases of exposure to domestic violence) have been considered. The type of violence was classified based on the guide for managers and health professionals for the Ministry of Health (17). In order to analyze the data obtained through the CSHQ, the variables were grouped into eight subcategories: bedtime resistance (BR), sleep onset delay (SOD), sleep duration, sleep anxiety (SA), night awakenings (NAs), parasomnias, sleep-disordered breathing (SDB) and daytime sleepiness. The exclusion criteria have been the existence of developmental or psychiatric disorders (such as attention deficit and hyperactivity disorder and autism spectrum disorder) or the use of medication (psychostimulants, anticonvulsants or antihistamines) that might impact sleep $(1,16)$.

Regarding the statistical methodology, descriptive statistics have been used to present the results through absolute and relative frequencies, minimum and maximum values, arithmetic means and respective standard deviations. The distribution of the scores of the variables resulting from the application of the CSHQ has been tested for normality using the Kolmogorov-Smirnov test. The existence of associations between the presence of SDs with the types of violence, sex and age groups has been analyzed by using the Chi-Square test.

The comparison of factor scores and the total CSHQ score between sexes and types of violence has been performed by using the Mann-Whitney test and, between age groups, the Kruskal-Wallis test. All statistical procedures have been performed by using the IBM SPSS Statistics 
24 , adopting a significance level of $p \leq 0.05$. The sample size calculation has been based on the number of monthly appointments of the analyzed age group - an average of 24 visits per month with a minimum total of 117 children.

\section{Results}

The research population comprised 129 children, victims of child violence or exposed to domestic violence, who were treated at the reference center. Six children have been excluded from the research due to the diagnosis of developmental or psychiatric disorder or the use of medication (psychostimulants, anticonvulsants or antihistamines). The sample profile has shown a predominance of girls 59.3\% $(n=73)$ and an age ranging from 2 to 10 years old with an average of $6.2 \pm 2.4$ years old. The most prevalent age range has been between 4 and 7 years old $48.8 \%$ ( $n=60$ ). Nearly two-thirds of the sample $66.7 \%(n=82)$ presented SDs.

Among the types of violence, we have found physical violence in $40.7 \%(n=50)$ of the children, followed by sexual violence $35.8 \% \quad(n=44)$, psychological violence $24.4 \%(n=30)$, neglect $14.6 \%$ $(n=18)$ and other types $4.1 \%(n=5)$. The number of occurrences has been calculated based on the sample size ( $n=123$ cases) and each type of violence in each sample case has been counted, totaling 102 (82.9\%) children who have suffered only one type of violence. Only one child has been identified with violence in three categories of the types of violence.

Regarding the SDs in relation to the variable gender and children's age groups, no significant association has been found $(p=0.092$ and $p=0.747$ respectively). As for the sleep domains (BR, SOD, sleep duration, SA, NAs, parasomnias, SDB and daytime sleepiness), significant differences between the sexes in the daytime sleepiness subcategory $(p=0.011)$ and the total CSHQ score ( $p=0.029$ ) have been found. In addition, there has been a significant difference between the age groups in the sleep domain subscales in the BR factor ( $p=0.033$ ) (Table 1).

TABLE 1 - Results of CSHQ scores by type of violence $(n=123)$.

\begin{tabular}{|c|c|c|c|c|c|c|c|}
\hline & $\begin{array}{c}\text { Sexual } \\
n=38\end{array}$ & $\begin{array}{l}\text { Physical } \\
n=33\end{array}$ & $\begin{array}{c}\text { Multiple } \\
\text { Notification } \\
n=22\end{array}$ & $\begin{array}{l}\text { Psychological } \\
\qquad n=21\end{array}$ & $\begin{array}{l}\text { Neglect } \\
n=6\end{array}$ & $\begin{array}{c}\text { Others } \\
n=4\end{array}$ & $p^{*}$ \\
\hline $\mathrm{BR}$ & $11.6 \pm 3.3$ & $9.6 \pm 3.3$ & $8.5 \pm 2.3$ & $11.0 \pm 3.2$ & $7.3 \pm 1.2$ & $11.0 \pm 5.8$ & 0.004 \\
\hline SOD & $1.5 \pm 0.7$ & $1.6 \pm 0.8$ & $1.9 \pm 1.0$ & $1.8 \pm 0.9$ & $1.3 \pm 0.8$ & $1.5 \pm 0.6$ & 0.578 \\
\hline $\begin{array}{l}\text { Sleep } \\
\text { duration }\end{array}$ & $4.3 \pm 1.5$ & $4.4 \pm 1.7$ & $4.1 \pm 1.7$ & $4.5 \pm 2.2$ & $3.7 \pm 0.5$ & $4.5 \pm 1.9$ & 0.884 \\
\hline SA & $7.5 \pm 2.5$ & $6.4 \pm 2.6$ & $6.4 \pm 2.4$ & $7.9 \pm 2.9$ & $4.8 \pm 1.6$ & $7.3 \pm 3.0$ & 0.039 \\
\hline NAs & $4.3 \pm 1.3$ & $4.3 \pm 1.4$ & $3.7 \pm 0.9$ & $4.4 \pm 1.0$ & $3.0 \pm 0.0$ & $3.5 \pm 1.0$ & 0.026 \\
\hline Parasomnias & $10.5 \pm 2.1$ & $9.5 \pm 2.3$ & $10.1 \pm 2.6$ & $10.1 \pm 2.5$ & $8.2 \pm 1.0$ & $9.0 \pm 0.8$ & 0.118 \\
\hline SDB & $3.9 \pm 1.2$ & $3.7 \pm 1.5$ & $3.9 \pm 1.4$ & $4.7 \pm 1.9$ & $3.0 \pm 0.0$ & $4.3 \pm 1.5$ & 0.067 \\
\hline $\begin{array}{l}\text { Daytime } \\
\text { sleepiness }\end{array}$ & $15.7 \pm 3.6$ & $14.8 \pm 2.7$ & $14.5 \pm 2.4$ & $15.8 \pm 3.0$ & $16.2 \pm 2.9$ & $15.5 \pm 4.4$ & 0.508 \\
\hline $\mathrm{CSHQ}$ & $55.0 \pm 8.0$ & $51.0 \pm 8.7$ & $50.1 \pm 6.5$ & $55.9 \pm 7.5$ & $45.5 \pm 3.9$ & $52.5 \pm 7.6$ & 0.004 \\
\hline
\end{tabular}

BR, bedtime resistance; CSH, Children's Sleep Habits Questionnaire; NAs, night awakenings; SA, sleep anxiety; $\mathrm{SDB}$, sleep disorders breathing; OD, sleep onset delay. "Kruskal Wallis test.

Regarding the results of the CSHQ scores by type of violence, there has been an association between physical violence and the following characteristics: BR $(p=0.011)$, sleep anxiety $(p=0.046)$ and score in the QSHQ $(p=0.011)$. Sexual violence has been associated with $B R(p=0.021)$ 
while psychological violence has been associated with changes in the sleep onset delay $(p=0.028)$ and SDB $(p=0.043)$. Finally, neglect has been associated with BR ( $p=0.002)$, SA ( $p=0.021)$, NAs $(p=0.009)$ and $Q S H Q$ score $(p=0.013)$. As for the other types of violence (OTV), there have been no significant associations

In order to assess the SDs according to the type of violence, only single cases by type of violence (rule of mutually exclusive sets) have been considered, to avoid bias in cases with two or more types of reported violence, leaving a specific sample of 102 cases $(n=102)$. SDs have been significantly associated with sexual and psychological violence as well as other forms of violence $(p=0.016)$ while regarding physical violence and neglect, there has been a lower prevalence of SDs (Figure 1).

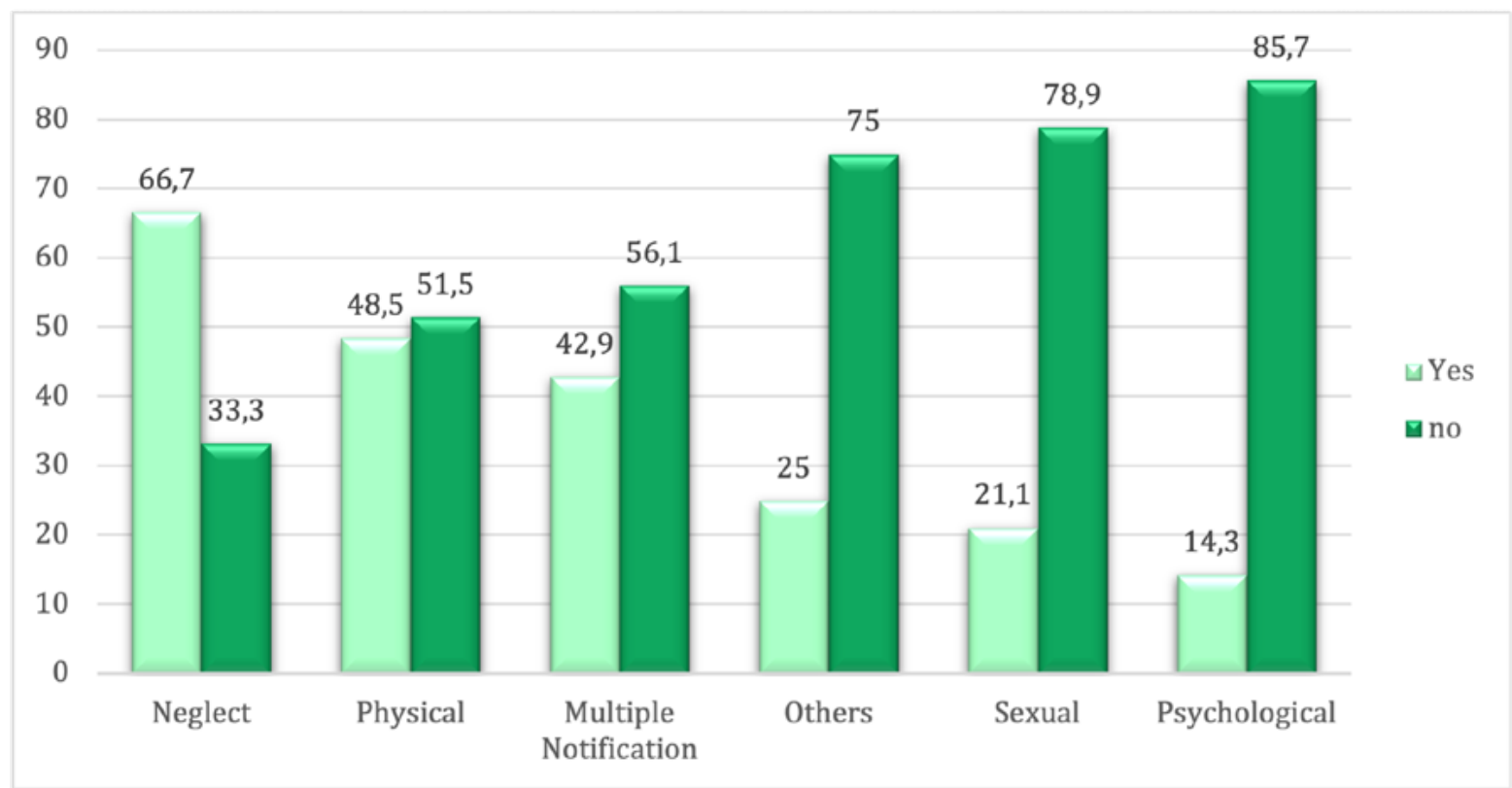

Figure 1 - Prevalence (\%) of sleep disorders by type of violence ( $n=123)$. Sleep disorders are associated with types of sexual and other types of violence $(p=0,016)$. Analysis based on the Kruskal Wallis test.

Presented in Table 1, BR typifies violence: sexual (11.6 points), psychological and other types (11.0 points each). SA typifies psychological violence (7.9 points), sexual violence (7.5 points) and other forms of violence (7.3 points). NAs typifies psychological (4.4 points), sexual and physical (4.3 points each) violence. As for the data by types of violence, significant differences in SA $(p=0.039)$, NAs $(p=0.026)$ and BR $(p=0.004)$ and total score in the CSHQ ( $p=0.004)$ have been found.

\section{Discussion}

Childhood sleep presents some degree of prevalence of disorders without exposure to situations of violence. The fact that SDs in children not exposed to violence, according to a Portuguese study that applied the CSHQ questionnaire, occurs in a prevalence of $24.3 \%$ with an average age of $6.50 \pm 2.49$ points in a CSHQ score must be taken into account (18).

Comparing the child population that have experienced child violence events, SDs are shown in $66.7 \%$ of children with an average age of $6.2 \pm 2.4$ years old (in a CSHQ score), as observed in the present study. SDs are more prevalent in girls, whether in children exposed to violence or not (18).

In general, SDs are reported in the literature with a prevalence of 16 to $40 \%$ among children who have experienced child violence $(7,18)$. According to a study carried out in Japan that evaluated 273 institutionalized children who were victims of violence, an age group between 4 and 15 years old was observed, with an average age of 9.9 \pm 3.2 , almost equal sex ratio between genders and prevalence of SDs of $40 \%$. Regarding the type of violence, it was observed that approximately half of the children 
had suffered neglect (45.4\%), psychological abuse (53.1\%) and physical abuse (50.5\%), while $7.7 \%$ of the children had suffered sexual abuse (4). By comparing this information to the current study, the profile of the sample that has been evaluated shows a predominance of females (59.3\%) and an age range with the highest rate of sleep disturbance between 4 and 7 years old (48.8\%). Among the types of violence, physical violence has been found in $40.7 \%$ of the children, followed by sexual violence (35.8\%), psychological violence (24.4\%), neglect (14.6\%) and other types (4.1\%).

When analyzing the presence of SDs associated with each type of violence alone, a higher prevalence in relation to sexual violence (78.9\%), psychological violence $(85.7 \%$ ) and other forms of violence $(75 \%)$ - the witnessing of domestic violence - has been found. The OTV have been less prevalent.

By comparing the subcategories that characterize SDs through the CSHQ, it has been observed that, in children that have not suffered violence, there is an SD pattern with a predominance of parasomnias (confusional arousals, sleepwalking, night terrors, nightmares, sleep paralysis and nocturnal enuresis), bed resistance and $S A(16,18)$. Concerning children in the context of violence, the presence of daytime sleepiness, parasomnias and BR have been associated with the highest scores.

In relation to the high prevalence of SDs related to sexual violence among the children who have been evaluated, a sleep pattern with a significant predominance of BR has been observed. It has been assumed that violence is an uncontrollable and frightening experience that affects the regulation of affective and cognitive functions of the central nervous system, generating a state of increased excitement associated with SDs (19). When the children experience violation of their own body, they express the event somatically, since new sensations have been awakened and have not had the possibility of being integrated (20).

Sexually abused preschoolers have presented more dissociative symptoms than non-abused children, which is commonly understood as a protective response to traumatic events. An unstable cycle of sleep and wakefulness has been related to dissociative symptoms because it correlates with an unusual sleep pattern (for example, rapid eye movement fragmentation, sleep paralysis, nightmares, recurring dreams, waking dreams) (21).

Sexual abuse exposes the child to a situation of total helplessness. The adult who should be perceived as a source of protection becomes a source of disturbance and threat. The child feels unable to convey information about the violence and can even be inclined, due to the complexity of the relationship, to feel guilty (22). Prospectively, adults who experienced sexual violence during childhood may have a reflex of psychophysiological hyperstimulation due to hyperactivity of the hypothalamic-pituitary-adrenal axis that regulates the sleep-wake cycle (19).

Psychological violence, presented as the most prevalent type of violence associated with sleep disturbance in this study, shows sleep-disordered breathing and changes in SOD as significant characteristics. Concerning SDB, symptoms such as central sleep apnea, hypoventilation disorders and hypoxemia have been observed. Such changes result in daytime consequences such as hyperactivity, behavioral problems or learning difficulties (18).

Regarding psychological violence, a "caregiver pattern" has been observed, which conveys to the children the feelings of worthlessness and failure in relation to their actions. Guardians can make children feel that they are unloved, unwanted, or valuable only when meeting a parent's need. Emotional mistreatment can involve acts of omission (ignoring the need for interactions) or commission (rejecting, frightening). Children are negatively affected in cognitive, social, emotional and physical aspects of development (20).

This study has had interference in the evaluation of the SDs: the existence of the habit of sharing a bed, which has not been qualified among the data. Considering that this habit is performed by other members of the family and sometimes shared with the aggressor, there is a significant change in the sleep disturbance parameters assessed. 
Regarding the application of the CSHQ, the collection of information has had some limitations regarding the reliability of answers. Some of the informants who accompanied the children and provided the information were either not closely related to them or had been living with them for a short period or had not been living in the same house, not being aware of the current characteristics of their sleep pattern. Most of the reports were brought by the child's family or legal guardians. By the rules of the institution that provided childcare, the family member who accompanied the child could not be the possible aggressor.

Initially, the classification of children seen at the reference center as "victims of violence" was based on the suspicion of violence by complaint, which was followed by a clinical evaluation. Next, the information was verified through more sources of reports and legal confirmations. The reference center unit in Canoas did not have a combined expert assessment service with the Medical-Legal Department at the time.

Based on the data from this study, it is possible to conclude that there is a significant occurrence of SDs associated with situations of child violence. Certain types of violence have been found to have a greater negative impact on children's sleep habits. The type of violence can also be related to specific SDs. These results can help the professionals who are providing medical care to the children to pay attention to complaints of SDs, especially when it appears as an isolated complaint, and thus they can develop targeted approach strategies.

\section{Notes}

Part of this study was presented at the Brazilian Sleep Congress Pediatrics (October, O9 ${ }^{\text {th }}, 2019$ ) and at the Brazilian Sleep Congress (December, $20^{\text {th }}, 2019$ ).

\section{Funding}

This study was financially supported by the corresponding author.

\section{Conflicts of interest disclosure}

The authors declare no competing interests relevant to the content of this study.

\section{Authors' contributions}

All the authors declare to have made substantial contributions to the conception, or design, or acquisition, or analysis, or interpretation of data; to have drafted the work or revising it critically for important intellectual content; to have approved the version to be published.

\section{Availability of data and responsibility for the results}

All the authors declare to have had full access to the available data and they assume full responsibility for the integrity of these results.

\section{References}

1. Krug EG, Dahlberg LL, Mercy JA, Zwi AB, Lozano R. World report on violence and health. Geneva; 2002. https://doi.org/10.1016/s0140-6736(02)11133-0

2. Rates SMM, de Melo EM, Mascarenhas MDM, Malta DC. Violence against children: an analysis of mandatory reporting of violence, Brazil 2011. Ciênc. Saúde Colet. 2015:20(3):655-65. https://doi.org/10.1590/141381232015203.15242014

3. Nunes AJ, Sales MCV. Violence against children in Brazilian scenery. Ciênc. Saúde Colet. 2016;21(3):871-80. https://doi.org/10.1590/1413-81232015213.08182014

4. Okada M, Otaga M, Tsutsui T, Tachimori H, Kitamura S, Higuchi S, et al. Association of sleep with emotional and behavioral problems among abused children and adolescents admitted to residential care facilities in Japan. PLoS One. 2018;13(6):e0198123. https://doi. org/10.1371/journal.pone.0198123.

5. Silva CB, Bastos BLDA, Santos CR, Moraes MDS, Possuelo LG. Caracterização do perfil da violência sexual em crianças e adolescentes no Rio Grande do Sul. Rev Epidemiol Controle Infecç. 2016;1(1):65-74. http://dx.doi.org/10.17058/reci.v1i1.8223

6. Font SA, Berger LM. Child maltreatment and children's developmental trajectories in early to middle childhood. Child Dev. 2015;86(2):536-56. https://doi.org/10.1111/ cdev.12322

7. Demirci E. Non suicidal self-injury, emotional eating and insomnia after child sexual abuse: Are those symptoms related to emotion regulation? J Forensic Leg Med. 2018;53:17-21. https://doi.org/10.1016/j. jflm.2017.10.012. 
8. Wamser-Nanney R, Chesher RE. Trauma characteristics and sleep impairment among traumaexposed children. Child Abuse Negl. 2018;76:469-79. https://doi.org/10.1016/j.chiabu.2017.11.020

9. van der Kolk B. Commentary: The devastating effects of ignoring child maltreatment in psychiatry-a commentary on Teicher and Samson 2016. J Child Psychol Psychiatry. 2016:57(3):267-70. https://doi. org/10.1111/jcpp.12540

10. Cecil CAM, Viding E, McCrory EJ, Gregory AM. Distinct Mechanisms underlie associations between forms of childhood maltreatment and disruptive nocturnal Behaviors. Dev Neuropsychol. 2015:40(3):181-99. https:// doi.org/10.1080/87565641.2014.983636

11. Abajobir AA, Kisely S, Williams G, Strathearn L, Najman JM. Childhood maltreatment and adulthood poor sleep quality: a longitudinal study. Intern Med J. 2017:47(8):879-88. https://doi.org/10.1111/imj.13459

12. Langevin R, Hébert M, Guidi E, Bernard-Bonnin A-C, Allard-Dansereau C. Sleep problems over a year in sexually abused preschoolers. Paediatr Child Health. 2017;22(5):273-6. https://doi.org/10.1093/pch/pxx077

13. Baiden P, Fallon B, den Dunnen W, Boateng GO. The enduring effects of early-childhood adversities and troubled sleep among canadian adults: a populationbased study. Sleep Med. 2015:16(6):760-7. https://doi. org/10.1016/i.sleep.2015.02.527

14. Oh DL, Jerman P, Marques SS, Koita K, Boparai SKP, Harris NB, et al. Systematic review of pediatric health outcomes associated with childhood adversity. BMC Pediatr. 2018;18(1):83. https://doi.org/10.1186/s12887-018-1037-7

15. Glaser D. The effects of child maltreatment on the developing brain. Med Leg J. 2014;82(3):97-111. https:// doi.org/10.1177/0025817214540395

16. Silva FG, Silva CR, Braga LB, Serrão Neto A. Portuguese Children's Sleep Habits Questionnaire validation and cross-cultural comparison. J Pediatr (Rio J). 2014:90(1):78-84. https://doi.org/10.1016/i. jped.2013.06.009

17. Brasil. Ministério da Saúde. Secretaria de Atenção à Saúde. Departamento de Ações Programáticas Estratégicas. [lnternet] Linha de cuidado para a atenção integral à saúde de crianças, adolescentes e suas famílias em situação de violências: orientação para gestores e profissionais de saúde. Brasília: Ministério da Saúde; 2010 [cited 2021 Aug 10]. Available from: https://bvsms.saude.gov.br/bvs/publicacoes/linha_ cuidado_criancas_familias_violencias.pdf

18. Parreira AF, Martins A, Ribeiro F, Silva FG. IClinical validation of the portuguese version of the Children's Sleep Habits Questionnaire (CSHQ-PT) in children with sleep disorder and ADHDI. Acta Med Port. 2019;32(3):195201. https://doi.org/10.20344/amp.10906
19. Steine IM, Skogen JC, Krystal JH, Winje D, Milde AM, Grønli J, et al. Insomnia symptom trajectories among adult survivors of childhood sexual abuse: A longitudinal study. Child Abuse Negl. 2019;93:263-76. https://doi. org/10.1016/j.chiabu.2019.05.009

20. Jackson AM, Kissoon N, Greene C. Aspects of abuse: recognizing and responding to child maltreatment. Curr Probl Pediatr Adolesc Health Care. 2015:45(3):58-70. https://doi.org/10.1016/j.cppeds.2015.02.001

21. Hébert M, Langevin R, Guidi E, Bernard-Bonnin AC, Allard-Dansereau C. Sleep problems and dissociation in preschool victims of sexual abuse. J Trauma Dissociation 2016;18(4):507-21. https://doi.org/10.1080/15299732.2 016.1240739

22. Florentino BRB. As possiveis consequências do abuso sexual praticado contra crianças e adolescentes. Fractal Rev Psicol. 2015 Aug;27(2):139-44. https://doi. org/10.1590/1984-0292/805

\section{Lilian Bertoletti}

Physician graduated from the Universidade Luterana do Brasil (ULBRA) in Canoas, RS, Brazil.

\section{Fernanda Cristina Scarpa}

Master in Child and Adolescent Health from the Universidade Federal do Rio Grande do Sul (UFRGS) in Porto Alegre, RS, Brazil. Professor at the Universidade Luterana do Brasil (ULBRA) in Canoas, RS, Brazil.

\section{Michelli Osanai da Costa}

Gynecology and Obstetrics Doctor at the Santa Casa de Misericórdia of Porto Alegre (UFCSPA). Physician at the Institute of Reference Center for Child Care (CRAI) in Canoas, RS, Brazil.

\section{Eduarda Correa Freitas}

Doctor in Medicine from the Universidade Federal do Rio Grande do Sul (UFRGS), in Porto Alegre, RS, Brazil. Graduated in Biological Sciences from the Pontificia Universidade Católica do Rio Grande do Sul (PUCRS) in Porto Alegre, RS, Brazil

\section{Luana Goulart Marin}

Physician graduated from the Universidade Luterana do Brasil (ULBRA) in Canoas, RS, Brazil. 
Rafael Miranda De Marco

Physician graduated from the Universidade Luterana do Brasil (ULBRA) in Canoas, RS, Brazil.

\section{Rosemary de Oliveira Petkowicz}

Master in Human Movement Sciences from the Federal Universidade Federal do Rio Grande do Sul (UFRGS)

in Porto Alegre, RS, Brazil. Physician at the Institute of Reference Center for Child Care (CRAI) in Canoas, RS, Brazil.

\section{Mailing address}

Lilian Bertoletti

Universidade Luterana do Brasil

Curupaiti street, 148

90820-090

Porto Alegre, RS, Brazil

Os textos deste artigo foram conferidos pela Poá Comunicação e antes da publicação. 